\title{
First record of Tenuipalpus uvae De Leon, 1962 (Acari: Tenuipalpidae) in Brazil
}

\author{
Jeferson Luiz de Carvalho Mineiro ${ }^{1 *}$, Ronald Ochoa $^{2}$, Maria do Socorro Miranda de Sousa ${ }^{3}$, Manoel \\ Guedes Correa Gondim Júnior ${ }^{4}$, Ezequiel da Glória de Deus ${ }^{5}$ and Ricardo Adaime ${ }^{5}$ \\ 1 Centro Experimental do Instituto Biológico, Laboratório de Acarologia, Rodovia Heitor Penteado km 3, CEP 13092-543, Campinas, SP, Brazil. \\ 2 USDA, ARS, Systematic Entomology Laboratory. BARC-West, Bldg. 005, Room 137 Beltsville, Maryland 20705, USA. \\ 3 Universidade do Estado do Amapá, Av. Presidente Vargas 650, CEP 68906-970, Macapá, AP, Brazil. \\ 4 Universidade Federal Rural de Pernambuco, Departamento de Agronomia, Área de Fitossanidade. Rua Dom Manoel de Medeiros s/n, Dois \\ Irmãos, CEP 52171-900, Recife, PE, Brazil. \\ 5 Embrapa Amapá. Rodovia Juscelino Kubitschek, km 5, No. 2600, CEP 68903-419, Macapá, AP, Brazil. \\ * Corresponding author. E-mail: jefmin@hotmail.com
}

ABSTRACT: This is the first record of Tenuipalpus uvae De Leon (Tenuipalpidae) in Brazil. Specimens were collected from Spondias mombin L. (Anacardiaceae) in the states of Amapá (northern Brazil) and Pernambuco (northeast).

Spondias mombin L. is a perennial fruit tree, dispersed across tropical regions of the Americas, Africa and Asia. In Brazil it is found mainly in the northern and northeastern states, where its fruit, the hog plum, is known as taperebá, cajá-mirim or cajá. The hog plum is used in the preparation of fruit pulps, ice creams, nectars, jams, and juices (Sacramento and Souza 2000).

Few phytophagous mites have been reported on Spondias, namely: Diptilomiopus alagarmaliensis Mohanasundaram, Tegolophus spondiallus Mondal \& Chakrabarti, Vasates spondiasi Boczek \& Chandrapatya and Diptilomiopus cythereae (Chandrapatya), respectively on the species Spondias mangifera Willd., Spondias bipinnata Airy-Shaw \& Forman, and Spondias cytherea Sonn. (Acari: Eriophyoidea) (de Lillo and Amrine 2006). Among the
Tetranychidae, only Eotetranychus mastichi De Leon has been reported on Spondias sp. (Bolland et al. 1998).

In the municipality of Porto Grande $\left(00^{\circ} 36^{\prime} 13.3^{\prime \prime} \mathrm{N}\right.$, $51^{\circ} 27^{\prime} 19.5^{\prime \prime} \mathrm{W}$ ), state of Amapá (Figure 1), a preliminary survey of mites associated with the hog plum tree was conducted in a commercial plantation with approximately 1,000 plants. Ten samples were collected, each consisting of three leaves from the middle third of the plant (M.S.M. Sousa, 11/21/2010). The leaves were taken into the laboratory, where the material was screened. The mites were mounted in Hoyer's solution on permanent slides, for subsequent identification. We obtained a total of 15 specimens of Tenuipalpus uvae De Leon, 1962 (Acari: Tenuipalpidae) (immatures and female adults) from seven of the samples. Over the same period, at the campus of the Federal Rural

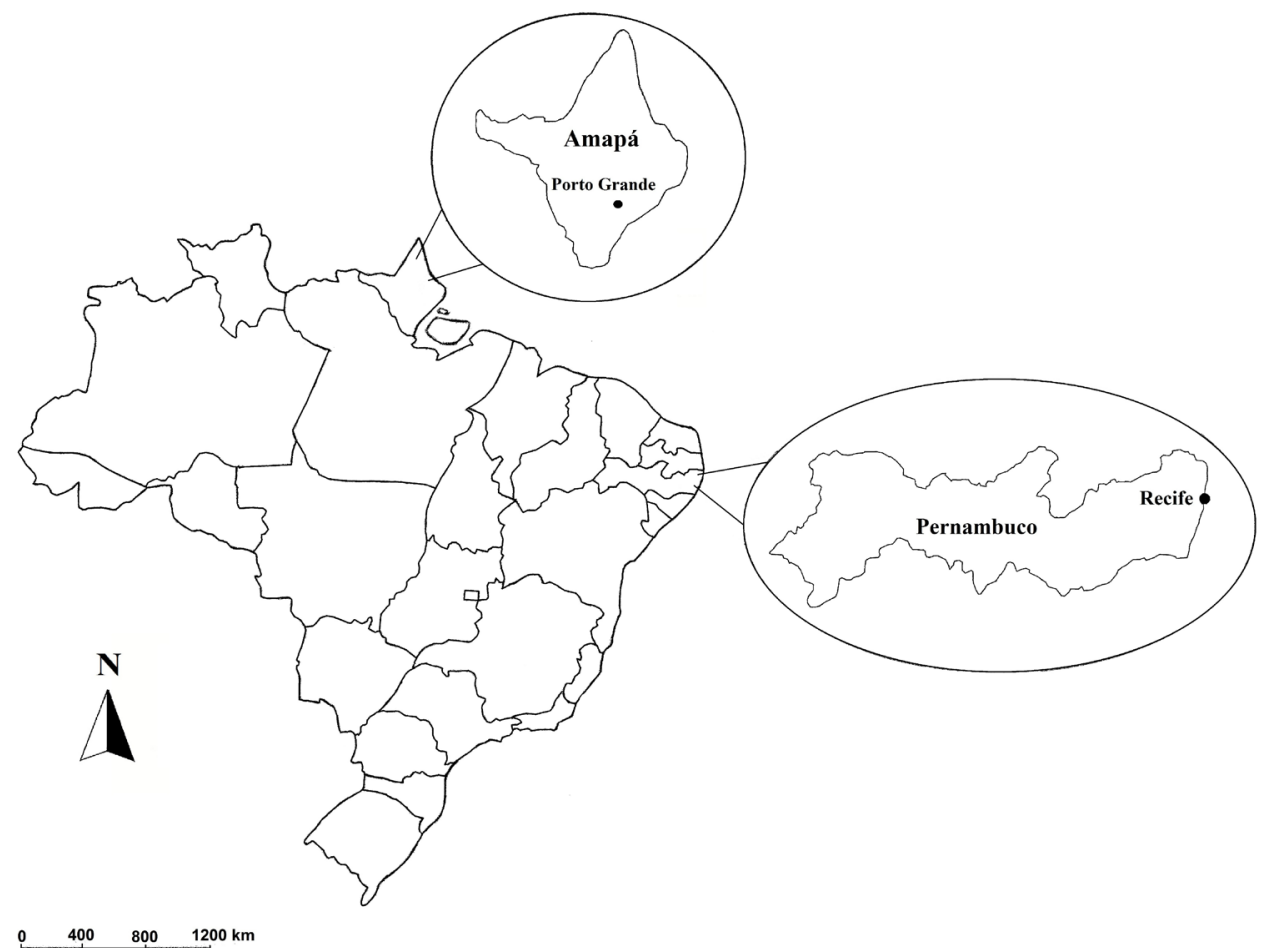

FIGURE 1. Map showing the first records of Tenuipalpus uvae De Leon, 1962 in Brazil, states of Amapá and Pernambuco. 
University of Pernambuco ( $8^{\circ} 00^{\prime} 59.0^{\prime \prime}$ S, $\left.34^{\circ} 56^{\prime} 39.7^{\prime \prime} \mathrm{W}\right)$ in Recife, Pernambuco (Figure 1), one female and one immature of T. uvae were obtained in a single sampling event on $S$. mombin (D.B. de Lima, 10/07/2010).

Tenuipalpus uvae is characterized by the rodlike dorsal setae Sci and Sce on the propodosoma; dorsal surface rugose, with sculptured polygonal design on dorsalcentral area; hysterosomal setae $c 3$ and $e 3$ short, sublanceolate, serrate; ventral surface finely strigate; genital setae slightly shorter than pregenitals.

Voucher specimens (7799 and 7800) are deposited in the "Geraldo Calcagnolo" Reference Collection of Mites at the Acarology Laboratory of the Biological Institute in Campinas, São Paulo, Brazil (ICMBio collection permit 35919-1).

In the family Tenuipalpidae, the genus Tenuipalpus presents the highest number of known species (306) (Mesa et al. 2009), of which only nine have been reported in Brazil (Flechtmann 1976; 1994; Feres and Hernandes 2006; Mesa et al. 2009). This report of T. uvae in Amapá (northern Brazil) and in Pernambuco (northeast) is the first for this species in Brazil, expanding the number of Tenuipalpus species reported to date in the country. This report also expands the known geographic distribution of T. uvae, which has already been reported in Mexico and Puerto Rico (De Leon 1962; 1967; Baker and Tuttle 1987; Mesa et al. 2009).

Knowing the distribution of this phytophagous species is vital on account of its relevance to the fields of ecology, zoogeography and pest control, especially in areas of agricultural interest
ACKNOWLEDGMENTS: We thank Conselho Nacional de Desenvolvimento Científico e Tecnológico - CNPq for the post-doctoral fellowship granted to JLCM (151579/2010-5), and also Patrícia Ramos Ferreira at the Reference Collection for technical support provided.

\section{Literature Cited}

Baker, E.W. and D.M. Tuttle. 1987. The false spider mites of Mexico (Tenuipalpidae: Acari). U.S. Department of Agriculture. Technical Bulletin 1706: 1-237.

Bolland, H.R., J. Gutierrez and C.H.W. Flechtmann. 1998. World catalog of the spider mites family (Acari: Tetranychidae). Boston: Brill. $392 \mathrm{pp}$.

De Leon, D. 1962. Two new false spider mites from Mexico and a new distribution Record. Proceedings of the Entomological Society of Washington 64(3): 203-205.

De Leon, D. 1967. Some mites of the Caribbean area. Part I. Acarina on Plants in Trinidad, West Indies. Lawrence: Allen Press, Inc. 66 pp.

de Lillo, E. and J.W. Amrine Jr. 2006. Catalog of the Eriophyoidea. A Working Catalog of the Eriophyoidea of the World. Accessible at https://insects. tamu.edu/research/collection/hallan/Acari/Family/Eriophyoidea. htm. Captured on 15 December 2013.

Feres, R.J.F. and F.A. Hernandes. 2006. Three new species of Tenuipalpus Donnadieu (Acari, Tenuipalpidae) from the State of São Paulo, Brazil. Zootaxa 1125: 57-68.

Flechtmann, C.H.W. 1976. Preliminary report on the false spider mites (Acari: Tenuipalpidae) from Brazil and Paraguay. Proceedings of the Entomological Society of Washington 78(1): 58-64.

Flechtmann, C.H.W. 1994. Tenuipalpus oliveirai, a new species (Acari, Prostigmata, Tenuipalpidae) from Brazil. Scientia Agricola 51(1): 184-187.

Mesa, N.C., R. Ochoa, W.C. Welbourn, G.A. Evans and G.J. de Moraes. 2009. A catalog of the Tenuipalpidae (Acari) of the World with a key to genera. Zootaxa 2098: 1-185.

Sacramento, C.K. and F.X. Souza. 2000. Cajá (Spondias mombin L.). Série Frutas Nativas, 4. Jaboticabal: Funep. 42 pp.

RECEIVED: April 2012

ACCEPTED: December 2013

PuBlished ONLINE: February 2014

EDITORIAL RESPONSIBILITY: Regiane Saturnino 